\title{
A case of hereditary hypophosphataemic rickets with hypercalciuria (HHRH)
}

\author{
M N Lucas ${ }^{1}$, Savithri Dias ${ }^{2}$ \\ Sri Lanka Journal of Child Health, 2006; 35:141-3
}

(Key words: hereditary hypophosphataemic rickets with hypercalciuriam, HRHH)

\section{Case Report}

A 3 year old boy was admitted to General Hospital, Kalutara with difficulty in getting up from the supine position for the past one year. There was progressively increasing difficulty in climbing stairs and rising from the squatting position for the same duration. There was no history of distal or upper limb weakness, no history of swallowing, speech or respiratory difficulty and no dyspnoea on exertion. His development was age appropriate. He was the product of a non consanguineous marriage. Birth history was normal with no history of fetal losses or still births. The baby was born at term with a birth weight of $2.5 \mathrm{~kg}$. There was no family history of a similar illness.

He was exclusively breast fed till 4 months of age and weaned thereafter. The child neither takes formula milk nor dairy products. Mother has left the child at 1 year of age and he is being looked after by the paternal grandmother. He belongs to the very low family income group. There is no past history of prolonged diarrhoea, weight loss, liver disease, polyuria, urinary tract infection or chronic renal disease. There is no family history of renal disease. The child has never been on anticonvulsants.

On presentation to General Hospital, Kalutara, he was $82 \mathrm{~cm}$ tall (below $3 \mathrm{SD}$ for age) and weighed 10 $\mathrm{kg}$ (Just below 3rd centile). Mild frontal and parietal bossing were present. There was metaphyseal widening in both wrists and ankles, mild lordosis with protuberant abdomen, rachitic rosary and a waddling gait. Gower sign was positive but there was no calf hypertrophy. There was no wasting. The tone was normal. Power was slightly reduced proximally in the lower limbs. The reflexes were normal. There was no sensory deficit. The child did not have bow legs, knock knees, kyphosis, scoliosis, enamel or pulp defects.

${ }^{1}$ Paediatric Registrar, ${ }^{2}$ Consultant Paediatrician, General Hospital, Kalutara.

(Received on 27 February 2006. Accepted on 20 April 2006)
The serum calcium was $2.1 \mathrm{mmol} / \mathrm{l}$ (normal range 2.2 - 2.7), serum phosphate $0.49 \mathrm{mmol} / \mathrm{l}$ (normal range 1.49-1.78) and serum alkaline phosphate $1161 \mathrm{IU} / \mathrm{L}$ (normal range $80-480 \mathrm{IU} / \mathrm{L}$ ). The liver function tests were within the normal range (SGOT $25 \mathrm{IU} / \mathrm{L}$, SGPT $16 \mathrm{IU} / \mathrm{L}$ ). Renal function tests were also within the normal range (blood urea $21 \mathrm{mg} \%$, serum Na 133 $\mathrm{mmol} / \mathrm{l}$, serum $\mathrm{K} 4.5 \mathrm{mmol} / \mathrm{l}$ ). The ultrasound scan of the abdomen was normal. The serum $\mathrm{pH}$ was 7.38 with serum $\mathrm{HCO}_{3} 24 \mathrm{mmol} / \mathrm{l}$. Urine for glucose (Benedict test) was negative. Urine phosphate excretion was $1.78 \mathrm{~g} / 24 \mathrm{hrs}$ (normal range 10-20 $\mathrm{mg} / \mathrm{kg} / 24 \mathrm{hr}$ ) Urine calcium excretion was 49.3 $\mathrm{mg} / 24 \mathrm{hrs}$ (normal $<2.4 \mathrm{mg} / \mathrm{kg} / 24 \mathrm{hr}$ ). Hypercalciuria is defined as urinary calcium excretion $>4$ $\mathrm{mg} / \mathrm{kg} / 24 \mathrm{hrs}$ i.e. $>40 \mathrm{mg} / 24 \mathrm{hrs}$ in this patient.

The laboratory findings of a low serum phosphorus, high urine phosphate excretion, high urine calcium excretion, absence of renal glycosuria, normal renal function and normal serum $\mathrm{pH}$ pointed towards the diagnosis of a rare subtype of 'primary phosphopenic' rickets known as hereditary hypophosphataemic rickets with hypercalciuria (HHRH).

\section{Discussion}

Three well-defined types of "primary phosphopenic rickets" have been delineated. The first is the welldocumented familial X-linked hypophosphataemia ${ }^{1}$. The second is the autosomal dominant hypophosphataemic bone disease ${ }^{2}$. The third is the autosomal recessive hereditary hypophosphataemic rickets with hypercalciuria (HHRH), first described in closely related members of a Bedouin tribe ${ }^{3}$. A few sporadic cases of HHRH have been reported from Europe, North America and Japan ${ }^{4,5,6}$. However, there are no previous reports of HHRH from Sri Lanka.

HHRH differs from the other types of primary phosphopenic rickets in several important ways (Table 1). 
Table 1

Differential diagnosis of primary phosphopenic rickets

\begin{tabular}{|c|c|c|}
\hline X-linked dominant & Autosomal recessive & Autosomal dominant \\
\hline Low urinary Ca excretion & Hypercalciuria & No hypercalciuria \\
\hline Mainly lower limb deformities & Mainly lower limb deformities & $\begin{array}{c}\text { Minor form with inconsistent } \\
\text { skeletal changes }\end{array}$ \\
\hline $\begin{array}{c}\text { Impaired conversion of } 25(\mathrm{OH}) \mathrm{D} \\
\text { to } 1,25(\mathrm{OH})_{2} \mathrm{D}\end{array}$ & $\begin{array}{c}\text { Intact conversion of } 25(\mathrm{OH}) \mathrm{D} \\
\text { to } 1,25(\mathrm{OH})_{2} \mathrm{D}\end{array}$ & $\begin{array}{c}\text { Impaired conversion of } 25(\mathrm{OH}) \mathrm{D} \text { to } \\
1,25(\mathrm{OH})_{2} \mathrm{D}\end{array}$ \\
\hline Reduced $1,25(\mathrm{OH})_{2} \mathrm{D}$ & Increased $1,25(\mathrm{OH})_{2} \mathrm{D}$ & Reduced $1,25(\mathrm{OH})_{2} \mathrm{D}$ \\
\hline $\begin{array}{c}\text { Treated with calcitriol and } \\
\text { phosphate }\end{array}$ & Treated with phosphate only & Treated with calcitriol only \\
\hline
\end{tabular}

Patients with $\mathrm{HHRH}$ have the following main features: short stature, rickets, increased renal phosphate clearance and hypophosphataemia with no additional renal tubular abnormalities, hypercalciuria with normal serum calcium levels and an elevated serum concentration of 1,25-dihydroxyvitamin D in the presence of suppressed parathyroid function ${ }^{3}$.

Three different pathogenic mechanisms have been proposed for the hypercalciuria viz. excessive bone resorption, a primary renal leak and intestinal hyperabsorption ${ }^{7}$. The most probable mechanism is intestinal hyperabsorption. The pivotal defect consists of a severe hereditary renal phosphate leak resulting in hypophosphataemia and phosphate depletion. This in turn stimulates renal 1-alpha hydroxylase, thus promoting the production of 1,25dihydroxyvitamin D and increasing its serum and tissue levels. Consequently, intestinal calcium and phosphorus absorption are augmented, with a resulting increase in the renal filtered calcium load and hypercalciuria. A second effect of enhanced intestinal calcium absorption would be suppression of parathyroid hormone secretion, which in turn would bring about a further increase in calciuria ${ }^{3}$.

Patients with HHRH were treated with neutral phosphate only, 1-2.5g of elemental phosphorus being given orally in 5 divided daily doses, the treatment being continued for $1-3$ years ${ }^{3}$. Within several weeks bone pain disappeared and muscular strength improved substantially in all patients. Radiological signs of rickets disappeared completely after 4- 9 months of treatment and serum alkaline phosphatase levels decreased concurrently ${ }^{3}$.

HHRH is underdiagnosed, due to its similarity to other hypophosphataemic syndromes in clinical, radiological and most biochemical parameters. Therefore, it is recommended that urinary calcium excretion, and if possible, serum 1,25dihydroxyvitamin D concentrations be measured in every patient with hypophosphataemic rickets before the initiation of any therapy. The correct diagnosis of HHRN is of immense therapeutic implications. Phosphate therapy alone could cause a complete remission in $\mathrm{HHRH}$, while the addition of active vitamin D metabolites, as is recommended in hypophosphataemic vitamin D resistant rickets, could cause deterioration in the patient's condition.

\section{References}

1. Carpenter TO. New perspectives on the biology and treatment of X-linked hypophosphataemic rickets. Paediatric Clinics of North America 1997; 44(2): 443-63.

2. Scriver CR, MacDonald W, Reade T. Hypophosphataemic nonrachitic bone disease: an entity distinct from X-linked phosphataemia in the renal defect, bone involvement and inheritance. Am J Med Genet 1977;1: 101-17.

3. Tieder M, Modai D, Samuel R, Arie R, Halabe A, Bab I, et al. Hereditary hypophosphataemic rickets with hypercalciuria. $N$ Eng $J$ Med 1985; 312: 611-7.

4. Nishiyama S, Inoue F, Matsuda I: A single case of hypophosphatemic rickets with hypercalciuria. J Pediatr Gastroenterol Nutr 1986; 5: 826-9.

5. Tieder M, Arie R, Bab I, Maor J, Liberman UA. A new kindred with hereditary hypophosphataemic rickets with hypercalciuria: implications for correct diagnosis and treatment. Nephron 1992; 62(2):176-81.

6. Sermet-Gaudelus I, Garabédian M, Dechaux M, Lenoir G, Rey J, Martin Tieder M. Hereditary hypophosphataemic rickets with hypercalciuria: Report of a new kindred. Nephron 2001;88(1):83-6.

7. Broadus $\mathrm{AE}$, Insogna $\mathrm{KL}$, Lang $\mathrm{R}$, et al. $\mathrm{A}$ consideration of the hormonal basis and phosphate leak hypothesis of absorptive hypercalciuria. J Clin Endocrinol Metab 1984; 58: $161-9$. 



\title{
A case of hereditary hypophosphataemic rickets with hypercalciuria (HHRH)
}

\author{
M N Lucas ${ }^{1}$, Savithri Dias ${ }^{2}$ \\ Sri Lanka Journal of Child Health, 2006; 35:141-3
}

(Key words: hereditary hypophosphataemic rickets with hypercalciuriam, HRHH)

\section{Case Report}

A 3 year old boy was admitted to General Hospital, Kalutara with difficulty in getting up from the supine position for the past one year. There was progressively increasing difficulty in climbing stairs and rising from the squatting position for the same duration. There was no history of distal or upper limb weakness, no history of swallowing, speech or respiratory difficulty and no dyspnoea on exertion. His development was age appropriate. He was the product of a non consanguineous marriage. Birth history was normal with no history of fetal losses or still births. The baby was born at term with a birth weight of $2.5 \mathrm{~kg}$. There was no family history of a similar illness.

He was exclusively breast fed till 4 months of age and weaned thereafter. The child neither takes formula milk nor dairy products. Mother has left the child at 1 year of age and he is being looked after by the paternal grandmother. He belongs to the very low family income group. There is no past history of prolonged diarrhoea, weight loss, liver disease, polyuria, urinary tract infection or chronic renal disease. There is no family history of renal disease. The child has never been on anticonvulsants.

On presentation to General Hospital, Kalutara, he was $82 \mathrm{~cm}$ tall (below $3 \mathrm{SD}$ for age) and weighed 10 $\mathrm{kg}$ (Just below 3rd centile). Mild frontal and parietal bossing were present. There was metaphyseal widening in both wrists and ankles, mild lordosis with protuberant abdomen, rachitic rosary and a waddling gait. Gower sign was positive but there was no calf hypertrophy. There was no wasting. The tone was normal. Power was slightly reduced proximally in the lower limbs. The reflexes were normal. There was no sensory deficit. The child did not have bow legs, knock knees, kyphosis, scoliosis, enamel or pulp defects.

${ }^{1}$ Paediatric Registrar, ${ }^{2}$ Consultant Paediatrician, General Hospital, Kalutara.

(Received on 27 February 2006. Accepted on 20 April 2006)
The serum calcium was $2.1 \mathrm{mmol} / \mathrm{l}$ (normal range 2.2 - 2.7), serum phosphate $0.49 \mathrm{mmol} / \mathrm{l}$ (normal range 1.49-1.78) and serum alkaline phosphate $1161 \mathrm{IU} / \mathrm{L}$ (normal range $80-480 \mathrm{IU} / \mathrm{L}$ ). The liver function tests were within the normal range (SGOT $25 \mathrm{IU} / \mathrm{L}$, SGPT $16 \mathrm{IU} / \mathrm{L}$ ). Renal function tests were also within the normal range (blood urea $21 \mathrm{mg} \%$, serum Na 133 $\mathrm{mmol} / \mathrm{l}$, serum $\mathrm{K} 4.5 \mathrm{mmol} / \mathrm{l}$ ). The ultrasound scan of the abdomen was normal. The serum $\mathrm{pH}$ was 7.38 with serum $\mathrm{HCO}_{3} 24 \mathrm{mmol} / \mathrm{l}$. Urine for glucose (Benedict test) was negative. Urine phosphate excretion was $1.78 \mathrm{~g} / 24 \mathrm{hrs}$ (normal range 10-20 $\mathrm{mg} / \mathrm{kg} / 24 \mathrm{hr}$ ) Urine calcium excretion was 49.3 $\mathrm{mg} / 24 \mathrm{hrs}$ (normal $<2.4 \mathrm{mg} / \mathrm{kg} / 24 \mathrm{hr}$ ). Hypercalciuria is defined as urinary calcium excretion $>4$ $\mathrm{mg} / \mathrm{kg} / 24 \mathrm{hrs}$ i.e. $>40 \mathrm{mg} / 24 \mathrm{hrs}$ in this patient.

The laboratory findings of a low serum phosphorus, high urine phosphate excretion, high urine calcium excretion, absence of renal glycosuria, normal renal function and normal serum $\mathrm{pH}$ pointed towards the diagnosis of a rare subtype of 'primary phosphopenic' rickets known as hereditary hypophosphataemic rickets with hypercalciuria (HHRH).

\section{Discussion}

Three well-defined types of "primary phosphopenic rickets" have been delineated. The first is the welldocumented familial X-linked hypophosphataemia ${ }^{1}$. The second is the autosomal dominant hypophosphataemic bone disease ${ }^{2}$. The third is the autosomal recessive hereditary hypophosphataemic rickets with hypercalciuria (HHRH), first described in closely related members of a Bedouin tribe ${ }^{3}$. A few sporadic cases of HHRH have been reported from Europe, North America and Japan ${ }^{4,5,6}$. However, there are no previous reports of HHRH from Sri Lanka.

HHRH differs from the other types of primary phosphopenic rickets in several important ways (Table 1). 
Table 1

Differential diagnosis of primary phosphopenic rickets

\begin{tabular}{|c|c|c|}
\hline X-linked dominant & Autosomal recessive & Autosomal dominant \\
\hline Low urinary Ca excretion & Hypercalciuria & No hypercalciuria \\
\hline Mainly lower limb deformities & Mainly lower limb deformities & $\begin{array}{c}\text { Minor form with inconsistent } \\
\text { skeletal changes }\end{array}$ \\
\hline $\begin{array}{c}\text { Impaired conversion of } 25(\mathrm{OH}) \mathrm{D} \\
\text { to } 1,25(\mathrm{OH})_{2} \mathrm{D}\end{array}$ & $\begin{array}{c}\text { Intact conversion of } 25(\mathrm{OH}) \mathrm{D} \\
\text { to } 1,25(\mathrm{OH})_{2} \mathrm{D}\end{array}$ & $\begin{array}{c}\text { Impaired conversion of } 25(\mathrm{OH}) \mathrm{D} \text { to } \\
1,25(\mathrm{OH})_{2} \mathrm{D}\end{array}$ \\
\hline Reduced $1,25(\mathrm{OH})_{2} \mathrm{D}$ & Increased $1,25(\mathrm{OH})_{2} \mathrm{D}$ & Reduced $1,25(\mathrm{OH})_{2} \mathrm{D}$ \\
\hline $\begin{array}{c}\text { Treated with calcitriol and } \\
\text { phosphate }\end{array}$ & Treated with phosphate only & Treated with calcitriol only \\
\hline
\end{tabular}

Patients with $\mathrm{HHRH}$ have the following main features: short stature, rickets, increased renal phosphate clearance and hypophosphataemia with no additional renal tubular abnormalities, hypercalciuria with normal serum calcium levels and an elevated serum concentration of 1,25-dihydroxyvitamin D in the presence of suppressed parathyroid function ${ }^{3}$.

Three different pathogenic mechanisms have been proposed for the hypercalciuria viz. excessive bone resorption, a primary renal leak and intestinal hyperabsorption ${ }^{7}$. The most probable mechanism is intestinal hyperabsorption. The pivotal defect consists of a severe hereditary renal phosphate leak resulting in hypophosphataemia and phosphate depletion. This in turn stimulates renal 1-alpha hydroxylase, thus promoting the production of 1,25dihydroxyvitamin $\mathrm{D}$ and increasing its serum and tissue levels. Consequently, intestinal calcium and phosphorus absorption are augmented, with a resulting increase in the renal filtered calcium load and hypercalciuria. A second effect of enhanced intestinal calcium absorption would be suppression of parathyroid hormone secretion, which in turn would bring about a further increase in calciuria ${ }^{3}$.

Patients with HHRH were treated with neutral phosphate only, 1-2.5g of elemental phosphorus being given orally in 5 divided daily doses, the treatment being continued for $1-3$ years ${ }^{3}$. Within several weeks bone pain disappeared and muscular strength improved substantially in all patients. Radiological signs of rickets disappeared completely after 4-9 months of treatment and serum alkaline phosphatase levels decreased concurrently ${ }^{3}$.

HHRH is underdiagnosed, due to its similarity to other hypophosphataemic syndromes in clinical, radiological and most biochemical parameters. Therefore, it is recommended that urinary calcium excretion, and if possible, serum 1,25dihydroxyvitamin D concentrations be measured in every patient with hypophosphataemic rickets before the initiation of any therapy. The correct diagnosis of HHRN is of immense therapeutic implications. Phosphate therapy alone could cause a complete remission in $\mathrm{HHRH}$, while the addition of active vitamin D metabolites, as is recommended in hypophosphataemic vitamin D resistant rickets, could cause deterioration in the patient's condition.

\section{References}

1. Carpenter TO. New perspectives on the biology and treatment of X-linked hypophosphataemic rickets. Paediatric Clinics of North America 1997; 44(2): 443-63.

2. Scriver CR, MacDonald W, Reade T. Hypophosphataemic nonrachitic bone disease: an entity distinct from X-linked phosphataemia in the renal defect, bone involvement and inheritance. Am J Med Genet 1977;1: 101-17.

3. Tieder M, Modai D, Samuel R, Arie R, Halabe A, Bab I, et al. Hereditary hypophosphataemic rickets with hypercalciuria. $N$ Eng $J$ Med 1985; 312: 611-7.

4. Nishiyama S, Inoue F, Matsuda I: A single case of hypophosphatemic rickets with hypercalciuria. J Pediatr Gastroenterol Nutr 1986; 5: 826-9.

5. Tieder M, Arie R, Bab I, Maor J, Liberman UA. A new kindred with hereditary hypophosphataemic rickets with hypercalciuria: implications for correct diagnosis and treatment. Nephron 1992; 62(2):176-81.

6. Sermet-Gaudelus I, Garabédian M, Dechaux M, Lenoir G, Rey J, Martin Tieder M. Hereditary hypophosphataemic rickets with hypercalciuria: Report of a new kindred. Nephron 2001;88(1):83-6.

7. Broadus $\mathrm{AE}$, Insogna $\mathrm{KL}$, Lang $\mathrm{R}$, et al. $\mathrm{A}$ consideration of the hormonal basis and phosphate leak hypothesis of absorptive hypercalciuria. J Clin Endocrinol Metab 1984; 58: $161-9$. 